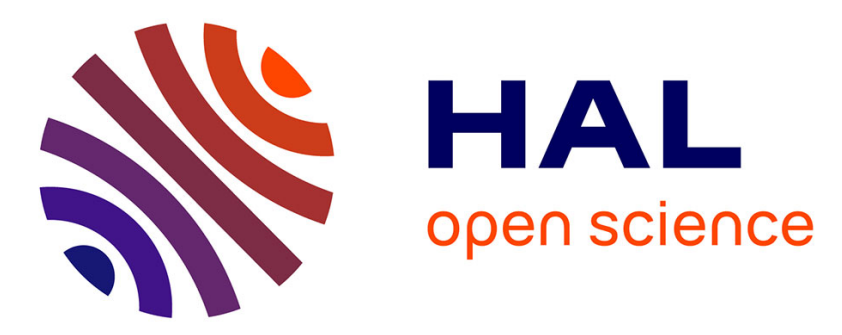

\title{
Energy cost of standing and circadian changes in energy expenditure in the preruminant calf
}

Isabelle Ortigues, Cécile Martin, Michel Vermorel, Yves Anglaret

\section{To cite this version:}

Isabelle Ortigues, Cécile Martin, Michel Vermorel, Yves Anglaret. Energy cost of standing and circadian changes in energy expenditure in the preruminant calf. Journal of Animal Science, 1994, 72 (8), pp.2131-2140. 10.2527/1994.7282131x . hal-02702959

\section{HAL Id: hal-02702959 \\ https://hal.inrae.fr/hal-02702959}

Submitted on 1 Jun 2020

HAL is a multi-disciplinary open access archive for the deposit and dissemination of scientific research documents, whether they are published or not. The documents may come from teaching and research institutions in France or abroad, or from public or private research centers.
L'archive ouverte pluridisciplinaire HAL, est destinée au dépôt et à la diffusion de documents scientifiques de niveau recherche, publiés ou non, émanant des établissements d'enseignement et de recherche français ou étrangers, des laboratoires publics ou privés.

\section{(c)(1)}

Distributed under a Creative Commons Attribution| 4.0 International License 


\title{
Energy Cost of Standing and Circadian Changes in Energy Expenditure in the Preruminant Calf ${ }^{1}$
}

\author{
I. Ortigues ${ }^{2}$, C. Martin, M. Vermorel, and Y. Anglaret
}

Laboratoire Croissance et Métabolismes des Herbivores, INRA, Theix, 63122 Saint Genès Champanelle, France

\begin{abstract}
An experiment was conducted with four preruminant calves to measure the energy cost and the diurnal pattern of physical activity in tethered, fed calves and to determine whether differences in activity could interfere with the interpretation of circadian changes in heat production. Measurements were carried out in large respiration chambers $(3,650 \mathrm{~L}$ of inner volume), and a computation method was presented that allowed the calculation of the energy cost of standing for each standing period. This cost averaged $449 \mathrm{cal} \cdot \mathrm{kg} \mathrm{BW}^{-1} \cdot \mathrm{h}^{-1}(\mathrm{SE}=41.6, \mathrm{n}=4)$. It represented a 23 to $27 \%$ increase in heat production above that measured in the lying state. This estimate
\end{abstract}

Key Words: Energy Expenditure, Energy Cost Of Activities, Circadian Rhythm, Behavior, Calves and its standard error were lower than values obtained by regression $\left(2,131 \mathrm{cal} \cdot \mathrm{kg} \mathrm{BW}^{-1} \cdot \mathrm{h}^{-1}, \mathrm{SE}=\right.$ $862.2, \mathrm{n}=8$ ). The energy cost of standing was highest after meal times and lowest at night. These variations could reflect the nonuniform activity patterns of calves while standing. The time spent standing per hour showed the same variations during the day as the energy cost of standing. Noteworthy, the elevated energy expenditure measured in the 1 st $\mathrm{h}$ after the morning meal was due to activity cost rather than to meal thermogenesis. Standardization of diurnal heat production profiles to a given activity pattern thus seemed to be necessary.

J. Anim. Sci. 1994. 72:2131-2140

\section{Introduction}

In neonatal calves, standing and related spontaneous physical activity may represent an increase in energy expenditure ( EE) of up to $46 \%$ above lying (Nienaber et al., 1987; Vermorel et al., 1989). In addition, the activity pattern of animals and probably the energy cost of standing (ECS) vary within the day (Toutain et al., 1977). It may, therefore, contribute to variations in EE to a larger extent than do the interanimal differences (van Es, 1972).

The objectives of the present study were to measure the energy cost and the diurnal pattern of physical activity of preruminant calves and to determine whether differences in activity could interfere with the interpretation of the circadian changes in EE. This trial was conducted on tethered, fed preruminant calves for which data are limited. It was part of a

\footnotetext{
${ }^{1}$ Acknowledgements are expressed to R. Souchet and C. Léoty for taking care of the animals and to J. Vernet for running the respiration chambers.

${ }^{2}$ To whom correspondence should be addressed.

Received November 15, 1993.

Accepted March 18, 1994.
}

larger experiment designed to study the contribution of organs and tissues to the diurnal changes in EE. Preliminary results have been reported (Martin et al., 1991).

Measurements were conducted in large respiration chambers characterized by a slow turnover rate of air that made it necessary to develop a computation method to improve the analysis of continuous measures. Preliminary results were presented elsewhere (Anglaret and Ortigues, 1994).

\section{Materials and Methods}

\section{Animals and Feeding}

A total of four male Holstein $\times$ Friesian calves were used. Calves were housed in individual pens that contained wood shavings, at an environmental temperature of $18^{\circ} \mathrm{C}$ and with no free access to water. They averaged $46.9 \mathrm{~kg} \mathrm{BW}(\mathrm{SE}=2.45)$ at $14 \mathrm{~d}$ of age, and $61.3 \mathrm{~kg}(\mathrm{SE}=3.9)$ at the time of measurements when calves were approximately $33 \mathrm{~d}$ old. Because these calves were simultaneously used in a study on in vivo tissue energy metabolism they were surgically equipped at the age of $14 \mathrm{~d}$ with blood catheters as described in Durand et al. (1988) for splanchnic 
tissues and in Ortigues et al. (1994) for the hindquarters. The experiment was conducted in a manner that was compatible with national legislation on animal care (Certificate of Authorization to Experiment on Living Animals, $n^{\circ} 02760$ delivered by the Ministry of Agriculture to $M$. Vermorel, Head of Research Unit).

Calves were fed a commercial milk-replacement $\operatorname{diet}(239 \mathrm{~g}$ of CP, $210 \mathrm{~g}$ of fat, $4.78 \mathrm{Mcal}$ of $\mathrm{ME} / \mathrm{kg}$ of DM) in two equal daily meals, distributed at 0830 and 1600. Feed allowances were calculated for a daily gain of $1 \mathrm{~kg} / \mathrm{d}$, assuming that maintenance $\mathrm{ME}$ requirements amounted to $100 \mathrm{kcal} / \mathrm{kg} \mathrm{BW} .75$, that the energy content of body gain averaged $2,500 \mathrm{kcal} / \mathrm{kg}$ gain for 3- to 5-wk-old calves, and that the efficiency of $\mathrm{ME}$ utilization for growth equaled 7 (van Es et al., 1966). Allowances were adjusted after surgery after the calves had resumed their normal eating habits (i.e. $d$ 7 after surgery) and left unchanged thereafter.

\section{Measurements}

Calves were weighed once weekly at a fixed hour (1330). Respiratory exchanges were measured on two successive days (d 12 and 13 on the set ration) by indirect calorimetry using the respiration chambers described by Vermorel et al. (1973) and maintained at $18^{\circ} \mathrm{C}$. Inner functional volume of the chambers was 3,650 L. Measurements started after only $1 \mathrm{~d}$ of adaptation because very young calves adapt almost immediately to the chambers ( $M$. Vermorel, unpublished data). Daily measurements were carried out over $23 \mathrm{~h}$ allowing for a .5 -h interruption before each meal for calibration checks of the gas analyzers. Measurements resumed at least $10 \mathrm{~min}$ before feed distribution. Outlet air flow, and inlet and outlet air $\mathrm{O}_{2}$ and $\mathrm{CO}_{2}$ concentration differences were recorded at discrete intervals once every $5 \mathrm{~min}$. The standing or lying postures of the calves were also recorded once every 5 min with a harness fitted around the chest of the calves and connected to an electrical switch.

The calculation of the apparent rates of $\mathrm{O}_{2}$ consumption at time $t\left(\mathrm{R}_{\mathrm{O} 2, \mathrm{t}}\right.$ in $\mathrm{L}$ of standard temperature and pressure [STP] $/ 5 \mathrm{~min}$ ) included the Haldane transformation in order to account for different inlet and outlet airflows when respiratory quotients differ from 1:

$$
\mathrm{R}_{\mathrm{O} 2, \mathrm{t}}=\mathrm{F}_{\text {out }, \mathrm{t}} \cdot\left(1.265 \mathrm{c}_{\mathrm{O} 2, \mathrm{t}}-.265 \mathrm{c}_{\mathrm{CO} 2, \mathrm{t}}\right),
$$

where $\mathrm{F}$ = outlet air flow from the chamber, (L of STP/ $5 \mathrm{~min}$ ), $\mathrm{c}=$ difference of fractional gas concentrations between inlet and outlet air (it should be mentioned here that rapid and thorough mixing of air was ensured in the chamber as described by Vermorel et al. (1973) in order to equilibrate gas concentrations throughout the chamber), and $t=$ time of measurement (minutes).

The Haldane transformation was not applied to the rate of $\mathrm{CO}_{2}$ production $\left(\mathrm{R}_{\mathrm{CO} 2, \mathrm{t}}\right)$ because the correction is negligible (McLean and Tobin, 1987). The rate of methane production was not considered because it is also negligible in preruminant calves.

The instantaneous respiratory gas exchange rates $\left(V_{t}\right.$ in $L$ of $\mathrm{STP} / 5 \mathrm{~min}$ ) were then calculated by including a correction factor for dead space. This correction was made necessary by the small turnover rate of air in the chamber (McLean and Watts, 1976). For our chambers of an inner volume (Vol) of $3,650 \mathrm{~L}$ ventilated by an average flow rate of $50 \mathrm{~L} / \mathrm{min}$, the turnover rate of air was $3,650 / 50=73 \mathrm{~min}$, implying that $95 \%$ of the maximum response was reached after $3 \times 73=219 \mathrm{~min}$. The correction was as follows: $\mathrm{V}_{\mathrm{t}}=$ $\mathrm{R}_{\mathrm{t}}+\left(\mathrm{Vol} \cdot\left[\mathrm{c}_{\mathrm{t}}-\mathrm{c}_{\mathrm{t}-5}\right]\right)$.

Energy expenditure was then calculated according to Brouwer (1965) excluding the urinary $\mathrm{N}$ and the methane factors. However, a $1 \%$ correction in $\mathrm{EE}$ was subsequently applied to account for it (Ortigues et al., 1993). Thus,

$$
\begin{gathered}
\mathrm{EE}(\text { kcalories })=\left[3.866 \mathrm{VO}_{2}(\mathrm{~L}, \mathrm{STP})\right. \\
\left.+1.200 \mathrm{VCO}_{2}(\mathrm{~L}, \mathrm{STP})\right] \times .99
\end{gathered}
$$

where $\mathrm{VO}_{2}$ and $\mathrm{VCO}_{2}$ are the volumes of $\mathrm{O}_{2}$ and $\mathrm{CO}_{2}$ respired by the calf.

\section{Analysis of Kinetics Data and Calculations}

Examination of simultaneous EE and posture data over time revealed that recorded incidences of standing were not always associated with an increase in $\mathrm{EE}$ values. For example, apparently excessive $E E$ values were measured while the calf was recorded as being lying (Figure 1a). Similarly, the increase in EE with standing was sometimes detected $5 \mathrm{~min}$ after the change in posture had been recorded. These situations made it difficult to calculate with confidence a basal EE for lying calves against which the standing levels would be compared. Consequently, criteria were defined in order to validate or correct if necessary, the imputation of $\mathrm{EE}$ values to each posture span, and in particular the synchronization between EE and posture changes.

The first step consisted of identifying the $\mathrm{EE}$ values that were not representative of the quietly lying position. These values might have two origins, the first of which might be behavioral. For example some agitation may take place while lying, or two successive posture changes may occur in between two posture recordings. Second, the increment in EE either due to standing or to any position change is known to be detected slowly with time as metabolic rate changes progressively (Colovos et al., 1970; Toutain et al., 1977) and might, therefore, be recorded with some time lag. Consequently, a unilateral confidence interval $(P<.005)$ was calculated for each lying period and any $\mathrm{EE}$ value greater than the upward limit (noted Lim 1) of this confidence interval was considered to be nonrepresentative of the quietly lying position. The 

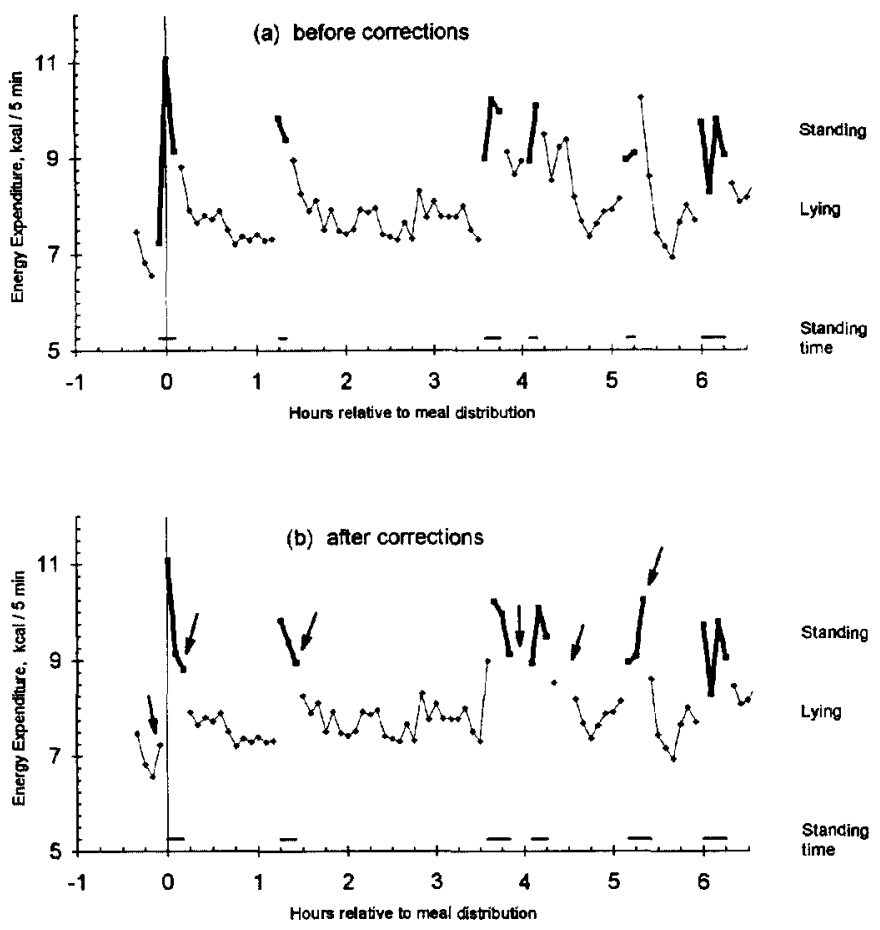

Figure 1. Example of changes in energy expenditure and posture in a preruminant calf. Meal distribution is indicated by a vertical line. Figure 1a was based on the observed data, whereas Figure $1 \mathrm{~b}$ used data corrected for their standing/lying imputation as described in the text. Arrows indicate the imputation changes.

confidence interval was determined in a conservative way $(P<.005)$ to account for the fact that dead space correction has been shown to amplify quantitatively the errors associated with gas analyzers as well as any instantaneous change in EE (Brown et al., 1984).

In case the first and second recordings after the calf had lain down were identified as nonrepresentative of the quietly lying posture, the second step of the analysis was to determine whether they were representative of the standing posture. Indeed, when the calf is first recorded as lying it might have been lying for either $4 \mathrm{~min} 59 \mathrm{~s}$ or for $1 \mathrm{~s}$, in which case the first "lying" EE measurement would in fact be representative of the 'standing' posture. Because posture had been recorded at 5-min intervals, any position change is associated with an average uncertainty of $5 / 2 \mathrm{~min}$ on the exact timing. Additionally the time lag in changes in EE mentioned above should be taken into account. Consequently, a provisional ECS ( $\Delta$ prov) was calculated as the difference between the average of all standing $\mathrm{EE}$ values of the relevant period and the average EE of the preceding and subsequent lying $\mathrm{EE}$ values (as recorded). The questionable data were then considered as representative of the standing posture if they were superior to "average lying $\mathrm{EE}+1 / 2 \Delta$ prov" ( $\operatorname{Lim} 2)$.

The other EE values which had been identified as non-representative of the quietly lying posture were omitted from the data set if at least two such values were obtained successively. Indeed, interpretation of such intermediate values would have required either more frequent posture recordings or measuring the intensity of physical activity. Nevertheless when only one isolated $\mathrm{EE}$ value was found to be non-representative of the quietly lying posture, this data point was not omitted because it could be the result of an amplification of measurement errors due to the calculation method used.

The final step of the data analysis concerned the first recording of each standing period. It proved necessary to check whether such values were representative of the standing posture (i.e., that the calf had been standing long enough for EE changes to be measured). The EE values were compared to $\operatorname{Lim} 2$ as described above.

Data were examined according to these criteria and decisions were made (Table 1 ) to validate or modify the imputation of $\mathrm{EE}$ values to the quietly lying or

Table 1. Criteria used to validate or modify the timing of posture changes (standing, lying) in relation to energy expenditure $(\mathrm{EE})$ changes measured in preruminant calves at 5-minute intervals in large respiration chambers

\begin{tabular}{|c|c|c|c|}
\hline \multirow[b]{2}{*}{ Individual $\mathrm{EE}$ data } & \multicolumn{2}{|c|}{$\begin{array}{l}\text { Conditions for } \\
\text { nonrepresentativeness } \\
{ }^{a} \text { of the }\end{array}$} & \multirow[b]{2}{*}{ Decision } \\
\hline & Lying posture & Standing posture & \\
\hline \multicolumn{4}{|l|}{ During a "lying" period } \\
\hline One isolated $\mathbf{E E}$ value & $\mathrm{EE}>\lim 1$ & - & $\begin{array}{l}\text { Conservative decision of maintaining it as } \\
\text { "lying" }\end{array}$ \\
\hline Several successive EE values & $\mathrm{EE}>\lim 1$ & - & Elimination from the "lying" period \\
\hline First recording after a standing period & $\mathbf{E E}>\lim 1$ & $\mathrm{EE}>\lim 2$ & Attribution to the "standing" period \\
\hline Second recording after a standing period & $\mathrm{EE}>\lim 1$ & $\mathrm{EE}>\lim 2$ & $\begin{array}{l}\text { Attribution to the "standing" period if the } \\
\text { attribution to the preceding EE value has } \\
\text { also been modified }\end{array}$ \\
\hline \multicolumn{4}{|l|}{ During a "standing" period } \\
\hline First recording of the standing period & - & $E E<\lim 2$ & Attribution to the "lying" period \\
\hline
\end{tabular}

${ }^{a} \operatorname{Lim} 1$ and $\lim 2$ are defined in the text. 
standing periods. The duration of the different periods was also modified as a consequence.

An example of the partition of $\mathrm{EE}$ values between the lying and standing periods is given in Figure 1a for the observed data and in Figure $1 \mathrm{~b}$ after data had been corrected as described above.

The ECS was then calculated using the modified profiles. For each standing period, a baseline was calculated as the average of six $\mathrm{EE}$ values of the preceeding and six $\mathrm{EE}$ values of the subsequent quietly lying periods. The ECS was thus taken to be the difference between the standing and the baseline EE values; it was expressed per unit of time.

Subsequently these values and the modified profiles were used to reconstitute the energy expenditure of calves that would have been obtained if they had been either always lying quietly or always standing. For the always lying profiles hourly $\mathrm{EE}$ were calculated as the sum of the measured lying EE values and of the baseline values for the standing periods. As for the standing profiles, the $\mathrm{EE}$ measured in each lying period was first raised by adding to each EE value an ECS, which was the average of the ECS measured in the two adjacent standing periods. The hourly standing EE was then calculated as the sum of these values and of the standing EE.

\section{Statistical Analyses}

Changes in EE, standing time, or other variables with time were analyzed using the univariate Repeated Measures Analysis of SAS (1987). Two repeated measures factors were used, "day of measurement" and "hour." Because respiratory exchange measurements were interrupted before each meal, separate analyses were conducted for each of the between meals intervals. The Huynh Feld epsilon ( HF Eps) adjustment factor of the F test was used to account for unequal correlations between repeated measures (Homer, 1989). This factor is reported in addition to the standard error of treatment means
( $\mathrm{SEM}=\sqrt{[\text { residual mean } \text { square/number of observa- }}$ tions per treatment]). Means were compared by orthogonal contrasts. In the Results section, no results are specifically reported for the effect of "day of measurement" or the interaction "day of measurement $x$ hour" because no significant differences were ever noted $(P>.10)$.

Other results were compared by Student's $t$ test.

\section{Results}

\section{Body Weight Gains}

All calves recovered well from surgery and were back on full feed 4 to $7 \mathrm{~d}$ after surgery. The ADG of the catheterized calves averaged $707 \mathrm{~g} / \mathrm{d}(\mathrm{SE}=104.0)$ between $\mathrm{d} 1$ and 14 .

\section{Observed Postprandial Changes in Energy Expenditure, Standing Time, and Posture}

Hourly EE was calculated by cumulating instantaneous EE values over 60 -min periods, timed from the beginning of each meal (Tables 2 and 3 ).

In the 1st $\mathrm{h}$ after the morning meal, $\mathrm{EE}$ averaged $2.21 \mathrm{kcal} \cdot \mathrm{kg} \mathrm{BW}^{-1} \cdot \mathrm{h}^{-1}$. It decreased significantly $(P<$ $.03)$ to an average value of $1.98 \mathrm{kcal} \cdot \mathrm{kg} \mathrm{BW}^{-1} \cdot \mathrm{h}^{-1}$ for the following $6 \mathrm{~h}$. This effect was related to a significant drop $(P<.01)$ in the time spent standing from the 2 nd $h$ onward after the morning meal (Table 2 ). Recorded standing time remained unchanged between $\mathrm{h} 2$ to 6 and tended to increase again (NS) on the last hour before the evening meal. The higher standing time measured during $h 1$ was also accompanied by a tendency (NS) for a higher number of position changes (Table 2).

Hourly EE decreased with time after the evening meal $(P<.001)$ (Table 3 ). Overall, no statistical differences were noted between $\mathrm{h} 1$ to 6 , or 7 to 11 , or 12 to 16 . The general decrease was partly but not entirely related to the time spent standing. Recorded

Table 2. Hourly averages in energy expenditure, recorded and corrected standing time, and recorded number of posture changes measured in preruminant calves after the morning meal plus estimates of the energy costs of standing obtained by regression

\begin{tabular}{|c|c|c|c|c|c|c|c|c|c|c|}
\hline \multirow[b]{2}{*}{ Item } & \multicolumn{7}{|c|}{ Hours after the morning meal } & \multirow{2}{*}{$\begin{array}{c}\text { SEM } \\
(\mathrm{n}=4)\end{array}$} & \multirow{2}{*}{ HF Eps ${ }^{a}$} & \multirow{2}{*}{$\begin{array}{l}\text { Hour } \\
\text { effect }\end{array}$} \\
\hline & 1 & 2 & 3 & 4 & 5 & 6 & 7 & & & \\
\hline Energy expenditure, kcal $\cdot \mathrm{kg} \mathrm{BW}^{-1} \cdot \mathrm{h}^{-1}$ & 2.21 & 1.95 & 1.96 & 2.00 & 1.97 & 1.93 & 2.02 & .066 & 1 & $P<.03$ \\
\hline Recorded standing time, $\mathrm{min} / \mathrm{h}$ & 35.0 & 8.8 & 8.8 & 11.2 & 12.5 & 11.9 & 17.5 & 5.43 & .62 & $P<.01$ \\
\hline Corrected standing time, $\mathrm{min} / \mathrm{h}$ & 36.8 & 13.8 & 12.5 & 13.2 & 13.1 & 11.2 & 18.1 & 5.76 & .64 & $P<.02$ \\
\hline Recorded number of posture changes & 2.5 & 1.25 & 1.5 & 1.5 & 1.4 & 1.9 & 1.8 & .38 & .88 & NS \\
\hline Energy cost of standing, cal $\cdot \mathrm{kg} \mathrm{BW}^{-1} \cdot \mathrm{h}^{-\mathbf{1}^{\mathrm{b}}}$ & $\begin{array}{l}1,112 \\
(113.0)\end{array}$ & $\begin{array}{l}100 \\
(439.0)\end{array}$ & $\begin{array}{l}420 \\
(548.2)\end{array}$ & $\begin{array}{l}1,259 \\
(499.1)\end{array}$ & $\begin{array}{l}250 \\
(311.0)\end{array}$ & $\begin{array}{l}940 \\
(454.6)\end{array}$ & $\begin{array}{c}646 \\
(432.3)\end{array}$ & - & - & - \\
\hline
\end{tabular}

\footnotetext{
aHuynh Feld epsilon.

${ }^{b}$ Estimates of the energy cost of standing corresponded here to the slopes of the regression equations calculated between hourly energy expenditure and standing time $(n=8)$ from corrected data. The associated standard errors are shown in parentheses.
} 
standing time was significantly higher in the 1 st $\mathrm{h}$ after the evening meal $(35 \mathrm{~min} / \mathrm{h})$ than for all following hours. Thereafter, it decreased regularly until the 9 th $h$ after the evening meal. Standing time remained stable during the early hours of the morning (between $\mathrm{h} 9$ to 15 ) and increased again before the morning meal.

Overall, calves spent $23.6 \%$ of the time standing. They generally remained standing for short periods of time. The 10- and 15-min standing periods were the most frequent (Table 4).

\section{Modifications Introduced by Kinetics Data Analysis}

The modifications introduced by the analysis of kinetics data resulted in a significant lengthening of the average time spent standing during the day by 56 $\min (\mathrm{SE}=6.7)$ on average, from $326(\mathrm{SE}=30.5)$ to $382(\mathrm{SE}=33.8) \mathrm{min} / \mathrm{d}$. However, this increase was smaller than the measurement errors $(5 \mathrm{~min}$ per standing period).

It was then tested whether the modifications introduced in the standing times were specific to certain periods of the day. Results showed that the increase in standing time per hour averaged $2.4 \mathrm{~min} / \mathrm{h}$ and did not vary significantly over time. There were tendencies (NS) for these corrections to be more important on $\mathrm{h} 2$ and 3 after the morning meal as well as on $h 3,4,6$, and 12 after the evening meal. However, this effect did not seem to be related to the recorded standing time, or to the recorded number of posture changes (Tables 2 and 3 ).

It was subsequently checked whether the modifications applied to the standing time varied with the duration of each standing period. On average, each standing period was lengthened by $3.15 \mathrm{~min}$ ( $\mathrm{SE}=$ .32) whatever the duration of each period (Table 4). Thus, corrections resulted in a reduced occurrence of the 5- and 10-min standing periods. This effect was counterbalanced by a higher occurrence of standing periods of longer duration. Finally, the frequency of each type of correction applied seemed to be independent to the recorded duration of the standing periods (Table 4).

Overall, these results showed that the corrections applied had not been limited to very specific situations. The comparison of Figures $1 \mathrm{a}$ and $1 \mathrm{~b}$ shows the improvement brought to the synchronization between $\mathrm{HP}$ and posture changes.

\section{Energy Cost of Standing} Calculated by Linear Regression

Many authors working with large respiration chambers calculated the ECS by linear regression between $\mathrm{EE}$ and the time spent standing (Hörnicke, 1970; Baker et al., 1991; Henken et al., 1993). This method was first applied here using the corrected data.
Results obtained were quite variable depending on which values were used. The ECS was first calculated from the daily measurements made on each calf, it amounted to $2,131 \mathrm{cal} \cdot \mathrm{kg} \mathrm{BW}{ }^{-1} \cdot \mathrm{h}^{-1}(\mathrm{SE}=862.2, \mathrm{n}=$ 8 ). However, when using the hourly results, from all calves, the energy cost of standing was 802 cal $\cdot \mathrm{kg}$ $\mathrm{BW}^{-1} \cdot \mathrm{h}^{-1}(\mathrm{SE}=69.9, \mathrm{n}=184)$. A similar calculation was carried out for each hour postprandially and the ECS was found to vary between $-224(\mathrm{SE}=558.4$ ) and $1,268(\mathrm{SE}=473.1) \mathrm{cal} \cdot \mathrm{kg} \mathrm{BW}^{-1} \cdot \mathrm{h}^{-1}$ (Tables 2 and 3 ). Each of these latter calculations was conducted on a small number of observations $(n=8)$ and the percentage of variance explained by the regression model varied from 0 to $87 \%$. Such a variability makes it impossible to use these results to correct hourly EE results for unequal standing times.

\section{Energy Cost of Standing Calculated from Kinetics Data}

The ECS (expressed per unit of time) was then calculated directly as the difference between the baseline and the standing $\mathrm{EE}$ values.

The calculated ECS obtained after corrections for the four calves averaged $449 \mathrm{cal} \cdot \mathrm{kg} \mathrm{BW}^{-1} \cdot \mathrm{h}^{-1}(\mathrm{SE}=$ $41.6, \mathrm{n}=4)$. It was significantly higher $(P<.05)$ than that obtained before corrections ( $367 \mathrm{cal} \cdot \mathrm{kg} \mathrm{BW}^{-1} \cdot \mathrm{h}^{-1}$, $\mathrm{SE}=34.8, \mathrm{n}=4$ ), even though the calculated time spent standing had been increased by corrections as noted earlier. Average ECS varied between calves from 359 to $545 \mathrm{cal} \cdot \mathrm{kg} \mathrm{BW}^{-1} \cdot \mathrm{h}^{-1}$. This range could partly be explained by the general agitation level of each of the calves, as noted visually.

It was checked that the calculated ECS was independent of the time spent standing (Table 4). A high variability was noted in the results obtained for the short ( $5 \mathrm{~min}$ ) or long ( $\geq 40 \mathrm{~min}$ ) standing periods that resulted from the small numbers of observations available. It also stressed the difficulty of estimating the ECS for standing periods of short duration.

Because an ECS was calculated for each standing period, it was possible to test whether some diurnal variations existed. Calves did not always stand up every hour, so that some pooling was necessary. It was carried out on the following grounds: 1) the calves must have stood at least once in each interval and 2) hourly EE and standing times should not be significantly different within each interval. Because the 1st $\mathrm{h}$ following each meal was associated with higher $\mathrm{EE}$ and standing times, average ECS values were calculated for the following time intervals: h 1,2 to 4 , and 5 to 7 after the morning meal and $h 1,2$ to 4,5 to 7,8 to 10,11 to 13 , and 14 to 16 after the evening meal. Results showed (Table 5) that the ECS was significantly higher in the 1st $h$ after the morning meal than otherwise and that the significantly lowest values were obtained during the night ( $h 5$ to 16 after the evening meal). The ECS of the 1st $h$ after the evening meal tended to be higher than the ECS of the 


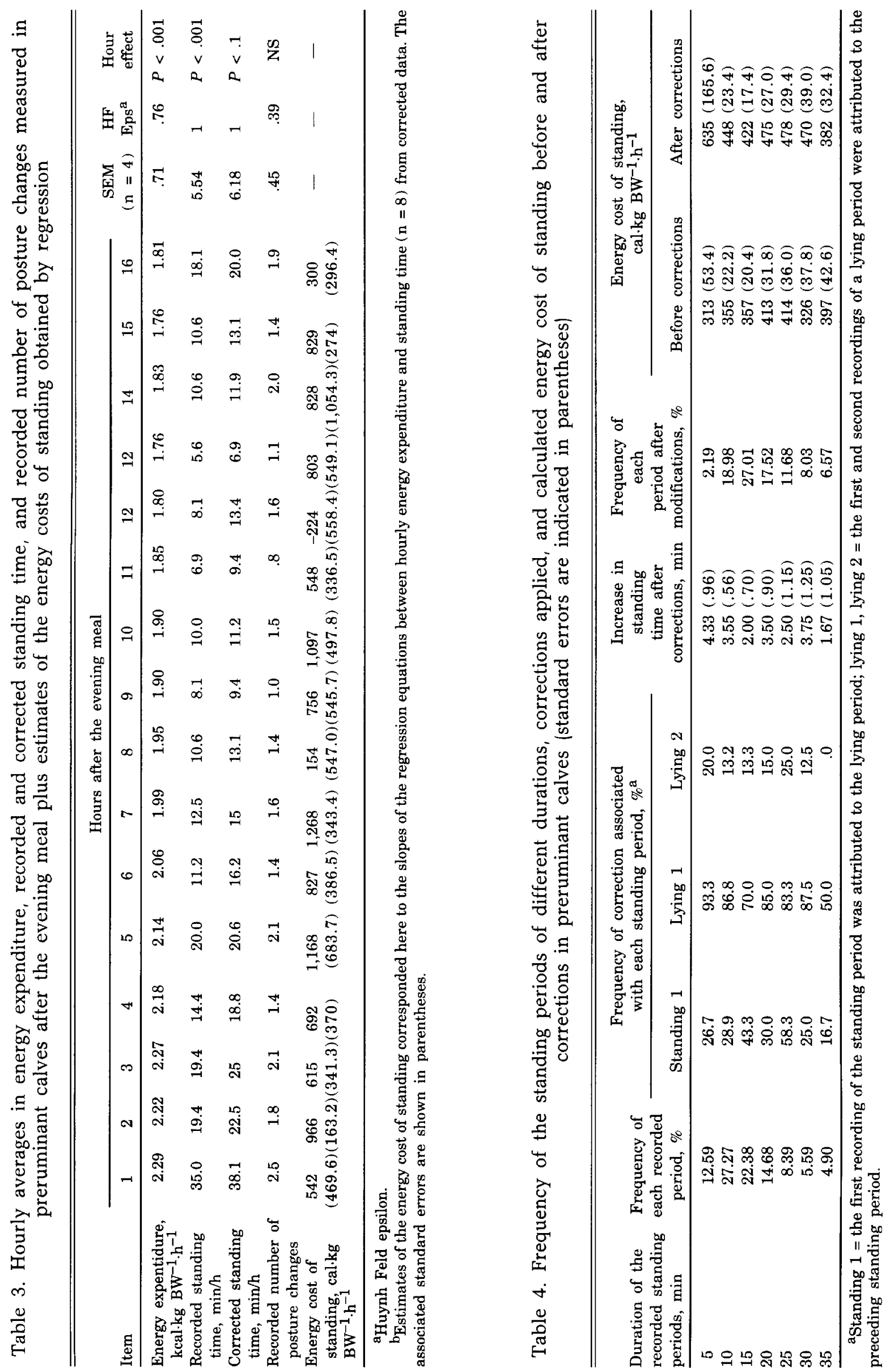


Table 5. Circadian changes in the energy cost of standing, measured in preruminant calves, calculated using corrected values

\begin{tabular}{|c|c|c|c|c|c|c|c|c|c|c|c|c|}
\hline \multirow[b]{2}{*}{ Item } & \multicolumn{3}{|c|}{$\begin{array}{l}\text { After the morning } \\
\text { meal, } \mathrm{h}\end{array}$} & \multicolumn{6}{|c|}{ After the evening meal, $h$} & \multirow[b]{2}{*}{$\begin{array}{c}\text { SEM } \\
(n=4)\end{array}$} & \multirow[b]{2}{*}{$\begin{array}{c}\mathrm{HF} \\
\mathrm{Eps}^{\mathrm{a}}\end{array}$} & \multirow[b]{2}{*}{$\begin{array}{l}\text { Hour } \\
\text { effect }\end{array}$} \\
\hline & h1 & $\begin{array}{l}\text { h2 } \\
\text { to } \\
\text { h4 }\end{array}$ & $\begin{array}{l}\text { h5 } \\
\text { to } \\
\text { h7 }\end{array}$ & h1 & $\begin{array}{l}\mathrm{h} 2 \\
\text { to } \\
\mathrm{h} 4\end{array}$ & $\begin{array}{l}\text { h5 } \\
\text { to } \\
\text { h7 }\end{array}$ & $\begin{array}{c}\mathrm{h} 8 \\
\text { to } \\
\mathrm{h} 10\end{array}$ & $\begin{array}{c}\text { h11 } \\
\text { to } \\
\text { h13 }\end{array}$ & $\begin{array}{c}\mathrm{h} 14 \\
\text { to } \\
\mathrm{h} 16\end{array}$ & & & \\
\hline $\begin{array}{l}\text { Energy cost of standing, } \\
\text { cal.kg } \mathrm{BW}^{-1} \cdot \mathrm{h}^{-1}\end{array}$ & 536 & 488 & 487 & 499 & 467 & 412 & 443 & 403 & 379 & 64.5 & .76 & $P<.03$ \\
\hline
\end{tabular}

${ }^{\text {a} H u y n h ~ F e l d ~ e p s i l o n . ~}$

following hours as well; however, this effect was not significant.

\section{Diurnal Changes in Energy Expenditure of Quietly Lying or Standing Animals}

The knowledge of the instantaneous ECS allowed the calculation of the diurnal changes in $\mathrm{EE}$ that would have been measured if the calves had always been either lying quietly or standing. In $\mathrm{h} 1$ to 7 after the morning meal, EE in the lying position averaged $1.86 \mathrm{kcal} \cdot \mathrm{kg} \mathrm{BW}^{-1} \cdot \mathrm{h}^{-1}$ and did not vary significantly postprandially (Table 6). The standing position resulted in a $27 \%$ higher average EE $(2.36 \mathrm{kcal} \cdot \mathrm{kg}$ $\mathrm{BW}^{-1} \cdot \mathrm{h}^{-1}$ ) that remained stable over time as well. After the evening meal, EE in the lying position averaged $2.02 \mathrm{kcal} \cdot \mathrm{kg} \mathrm{BW}^{-1} \cdot \mathrm{h}^{-1}$ from $\mathrm{h} 1$ to 6 ; it decreased significantly to $1.84 \mathrm{kcal} \cdot \mathrm{kg} \mathrm{BW}^{-1} \cdot \mathrm{h}^{-1}$ between $\mathrm{h} 7$ and 11 , and to $1.72 \mathrm{kcal} \cdot \mathrm{kg} \mathrm{BW}^{-1} \cdot \mathrm{h}^{-1}$ between $\mathrm{h} 12$ and 16 (Table 7). The standing posture increased EE by $23 \%$ on average and time effects were similar to those noted in the lying position after the evening meal.

\section{Discussion}

Increasing attention has recently been focused on the influence of standing time and its associated energy cost on the interpretation of whole animal or tissue EE. Indeed, the ECS has been shown to vary with the animal species (Nienaber et al., 1987), breed and level of feeding (Susenbeth and Menke, 1991), age (Baker et al., 1991), body fatness, and time of day
(Toutain et al., 1977). In addition, activity patterns are influenced by breed (Baker et al., 1991; Susenbeth and Menke, 1991), age (Baker et al., 1991), diet quality (Wenk and van $E_{\mathbb{s}}, 1976$ ), and level of feeding (Harris et al., 1989; Susenbeth and Menke, 1991). Consequently, changes in activity patterns of animals seemed to have biased comparisons of $\mathrm{EE}$ between normal or underfed animals (Harris et al., 1989).

When a large number of animals is used and when the experimental interest is limited to average $\mathrm{EE}$ within or between animals, the ECS has been reliably calculated using a regression approach (Hörnicke, 1970; Susenbeth and Menke, 1991). However, when experimental constraints restrict the number of animals that are used or when hourly changes in heat production are studied within animals, a more precise approach becomes necessary. The ECS values obtained by a regression approach with the present results were extremely variable due to a large scatter between individual data. Variability was greatly reduced when regressions were established on a large number of data points using hourly averages. The ECS determined in this manner (802 cal-kg $\mathrm{BW}^{-1} \cdot \mathrm{h}^{-1}$ ) was similar to the value of $901 \mathrm{cal} \cdot \mathrm{kg}$ $\mathrm{BW}^{-1} \cdot \mathrm{h}^{-1}$ measured in fasted newborn calves by Nienaber et al. (1987) using a different calculation method described further below. However, with the regression approach no distinction could be made between different animals and(or) different hours. In view of the results calculated directly, this distinction seemed to be important and it can be concluded that the regression approach cannot reliably be used in experiments such as the present one.

In the present experiment, the choice of using large respiration chambers instead of respiration hoods

Table 6. Hourly changes in energy expenditure of preruminant calves after the morning meal, assuming the calves would have been continuously lying quietly or standing (corrected values were used)

\begin{tabular}{|c|c|c|c|c|c|c|c|c|c|c|}
\hline \multirow{2}{*}{$\begin{array}{l}\text { Energy expenditure, } \\
\mathrm{kcal} \cdot \mathrm{kg} \mathrm{BW} \\
-1 \cdot \mathrm{h}^{-1}\end{array}$} & \multicolumn{7}{|c|}{ Hours after the morning meal } & \multirow{2}{*}{$\begin{array}{c}\text { SEM } \\
(n=4)\end{array}$} & \multirow{2}{*}{$\begin{array}{c}\mathbf{H F} \\
\mathbf{E p s}^{\mathrm{a}}\end{array}$} & \multirow{2}{*}{$\begin{array}{l}\text { Hour } \\
\text { effect }\end{array}$} \\
\hline & 1 & 2 & 3 & 4 & 5 & 6 & 7 & & & \\
\hline "Lying" animal & 1.83 & 1.84 & 1.86 & 1.88 & 1.86 & 1.85 & 1.88 & .037 & .65 & NS \\
\hline "Standing" animal & 2.36 & 2.35 & 2.32 & 2.38 & 2.37 & 2.33 & 2.35 & .573 & .22 & NS \\
\hline
\end{tabular}

${ }^{a}$ Huynh Feld epsilon. 
Table 7. Hourly changes in energy expenditure of preruminant calves after the evening meal, assuming the calves would have been continuously lying quietly or standing (corrected values were used)

\begin{tabular}{|c|c|c|c|c|c|c|c|c|c|c|c|c|c|c|c|c|c|c|c|}
\hline \multirow{2}{*}{$\begin{array}{l}\text { Energy expenditure, } \\
\text { kcal.kg } \mathrm{BW}^{-1} \cdot \mathrm{h}^{-1}\end{array}$} & \multicolumn{16}{|c|}{ Hours after the evening meal } & \multirow{2}{*}{$\begin{array}{c}\text { SEM } \\
(\mathrm{n}=4)\end{array}$} & \multirow{2}{*}{$\begin{array}{c}\mathbf{H F} \\
\mathrm{Eps}^{\mathrm{a}}\end{array}$} & \multirow{2}{*}{$\begin{array}{l}\text { Hour } \\
\text { effect }\end{array}$} \\
\hline & 1 & 2 & 3 & 4 & 5 & 6 & 7 & 8 & 9 & 10 & 11 & 12 & 13 & 14 & 15 & 16 & & & \\
\hline "Lying" animal & 2.01 & 2.03 & 2.07 & 2.06 & 1.99 & 1.94 & 1.89 & 1.86 & 1.84 & 1.81 & 1.78 & 1.71 & 1.71 & 1.76 & 1.69 & 1.73 & .048 & .28 & $P<.0001$ \\
\hline "Standing" animal & 2.49 & 2.51 & 2.52 & 2.49 & 2.43 & 2.37 & 2.31 & 2.30 & 2.27 & 2.25 & 2.20 & 2.11 & 2.12 & 2.17 & 2.09 & 2.15 & .048 & 1.00 & $P<.0001$ \\
\hline
\end{tabular}

aHuynh Feld epsilon.

(Brockway et al., 1969) was made in order to minimize the restraint stress imposed. on multicatheterized calves while allowing measurements to be carried out over several successive days. However, it incurred some methodological difficulties. Indeed, the study of instantaneous changes in the rates of gas exchanges by the calf is difficult in large respiration chambers compared with respiration hoods (Toutain et al., 1977), because the turnover rate of air in the chamber is much lower than the time scale of the phenomenon of interest (e.g., posture).

Some authors presented a method to calculate the ECS of animals placed in large respiration chambers (Nienaber et al., 1987). However, they did not seem to include a dead space-correction term in the computation of the instantaneous rates of gas exchanges such that the calculation of the ECS was somewhat complex. In addition, this method did not allow the estimation of the ECS of standing events that occurred in rapid succession. A more direct and simple method seemed preferable. The inclusion of a dead space-correction term in the calculation has the disadvantage of increasing the variability obtained between successive EE results (Brown et al., 1984).

This phenomenon is partly responsible for the lack of synchronization that was often noted between changes in posture and changes in EE. This lack of synchronization was also due to the measurement frequency of $5 \mathrm{~min}$ that was chosen as a compromise between obtaining sufficient information and somewhat limiting data storage and handling. To work directly on the recorded data seemed to result in an underestimation of the ECS through an overestimation of EE of calves in the lying state. The ECS was indeed $18 \%$ lower when calculated from the observed rather than from the corrected data. Therefore, the frequency of corrections applied to the first and second data points of each lying period was high and must have contributed to reducing the baseline level. The set of correction criteria that was elaborated tested whether data obtained after a posture change were representative of the lying or of the standing postures. The critical appraisal of the procedure used showed that the frequency of corrections applied to data around the standing events was relatively high but that the type of corrections was not dependent on the duration of the standing periods or on the hour of the day. This suggested that corrections were more specifically associated with methodological difficulties rather than to behavioral reasons. Indeed, in times of greater agitation (e.g., day vs night; meal times) one would have expected larger correction frequencies especially for data measured after the standing peaks, such was not the case. Corrections resulted in a significant increase in the calculated time spent standing in a day. However, this increase remained smaller than measurement error and did not lower the ECS. These elements suggest that the approach used here was quite robust. It improved the synchronization of posture and $\mathrm{EE}$ changes and thereby might have improved the reliability of the determination of the ECS in large respiration chambers. In addition, it allowed the estimation of the ECS even when multiple standing events occurred within a short period of time.

The ECS of preruminant calves calculated after corrections averaged $449 \mathrm{kcal} \cdot \mathrm{kg} \mathrm{BW}^{-1} \cdot \mathrm{h}^{-1}$. This value is intermediate between values obtained by Nienaber et al. (1987) for newborn, fasted preruminant calves that struggle to get up in the first hours of life (901 cal.kg $\mathrm{BW}^{-1} \cdot \mathrm{h}^{-1}$ ) and for older and thus less active ruminants ( $354 \mathrm{cal} \cdot \mathrm{kg} \mathrm{BW}^{-1} \cdot \mathrm{h}^{-1}$ ) showing an effect of age on ECS. Results obtained in ruminants as opposed to preruminants ranged from 60 to 354 cal $\cdot \mathrm{kg}$ $\mathrm{BW}^{-1} \cdot \mathrm{h}^{-1}$ (Osuji, 1974; Nienaber et al., 1987). A much wider range (143 to $717 \mathrm{cal} \cdot \mathrm{kg} \mathrm{BW}^{-1} \cdot \mathrm{h}^{-1}$ ) has even been noted (J. M. Brockway, Rowett Research Institute, Aberdeen, U.K., personal communication).

The ECS was independent of the duration of each standing period. This pointed to one limit of the procedure used here, which is the difficulty of detecting the energy expenditure associated with changing position (ARC, 1980). However, the method was sensitive enough to detect changes in the ECS with time during the day. These changes reflect the nonuniform activity patterns of calves while standing. For example, the higher ECS noted in the 1st $\mathrm{h}$ after the morning meal is probably due to an enhanced agitation of the calves. Indeed, calves stood longer in that hour and tended to change position more often. Visual observations confirm that young calves like to play after meals. Results obtained after the evening meal were similar even though the ECS eluded statistical significance. It cannot be excluded that the ECS after the meals have been slightly overestimated 
because of meal thermogenesis. Indeed, the determination of the quietly lying baseline of $\mathrm{EE}$ is more difficult after the meals than otherwise. It would require that the calves do not change position in the hours preceding and following the meals. Specific studies designed to elucidate this point would be necessary. By contrast, the lowest values for the ECS were measured at night (from 2000 onward). They could also be associated to the progressive reduction in the time spent standing and in the number of position changes during the night. This corresponded to a period during which calves were much quieter. These results confirm previous observations noted by Toutain et al. (1977).

Results reported here show the relevance of accounting for the EE associated with posture and spontaneous physical activity when studying the circadian and in particular the postprandial changes in EE. Average EE was significantly higher in the 1st $\mathrm{h}$ after the morning meal than subsequently. The reconstitution of the $\mathrm{EE}$ changes that would be observed in "always quietly lying" or "always standing" calves strongly suggests that this heat increment is due to posture rather than to meal thermogenesis. By contrast $\mathrm{EE}$ in the lying posture was higher from $\mathrm{h}$ 1 to 7 after the morning meal than during the night by $.29 \mathrm{kcal} \cdot \mathrm{kg} \mathrm{BW}^{-1} \cdot \mathrm{h}^{-1}$ on average. This would suggest that the major part of the increase in EE associated with meal intake, meal digestion, and absorption takes place over a long period of time. Shorter term changes could not be detected here using the hourly profiles. A slightly different situation was noted after the evening meal. Accounting for physical activity did not modify the statistical differences or absence of differences noted among hours after the evening meal. However, it lowered the magnitude by which EE decreased during the night. Similarly to what was observed in the morning, meal thermogenesis seemed to last over several hours ( $5 \mathrm{~h}$ in this case) even though it was of smaller magnitude. Indeed, average EE was higher after the evening meal than before by $.16 \mathrm{kcal} \cdot \mathrm{kg} \mathrm{BW}^{-1} \cdot \mathrm{h}^{-1}$ only (lying profile). This increase could arise from the combination of the effect noted in the morning and of the energy expended for lipid absorption and metabolism. In preruminant calves, it is known that milk curdles in the abomasum, which slows gastric emptying down and induces progressive lipid and protein absorption in the 5 to $7 \mathrm{~h}$ after the meal (Toullec et al., 1971; Bazin and Brisson, 1976; Durand and Bauchart, 1986). By contrast no increase in EE associated with lipid absorption and metabolism was detected 5 to $7 \mathrm{~h}$ after the evening meal even though lipid absorption is also elevated then.

Modification of the EE profile after standardization of results to a given activity pattern has also been reported in swine by Henken et al. (1993). These authors showed that the activity-free $\mathrm{EE}$ of pigs varied less within a day than total EE did. Similarly to our present results, they observed that $\mathrm{EE}$ was at its maximum at feeding times mostly because of increased physical activity of the animals.

In conclusion, the present paper stresses the importance of elaborating strategies to account for physical activity in any energy metabolism study. Strategies and the associated data analysis approaches largely depend on the equipment available. In addition to the choice to be made between respiration chambers and respiration hoods that determine the response time via the rate of air turnover, other technical aspects have to be considered.

First, the frequency of gas analysis and recording, and the possibility of integrating results over a certain period of time will partly determine the data analysis method to be used. For example, preliminary results obtained in our laboratory show that more frequent but still discrete measurements of gas analysis (e.g., every minute) lead to an extremely high variability of the baseline $\mathrm{EE}$, which is even more difficult to interpret. By contrast, Brown et al. (1984) showed that using the average of virtually simultaneous readings of gas greatly reduced the random variability of the baseline. Consequently the integration of very frequent (e.g., second by second) readings over a certain period of time (one to a few minutes) might improve the results.

Second, as far as measurement of physical activity is concerned, more frequent recordings of posture are definitely required. In addition, measurements of the intensity of physical activity in a given posture (agitation), such as those conducted by Henken et al. (1993), would be of great help to interpret results.

\section{Implications}

The present paper shows the necessity to standardize the energy expenditure of calves to a given activity pattern in order to reliably compare and interpret the diurnal changes in energy expenditure. The required measurements can be conducted in large respiration chambers even though the time scale of the activities of interest is shorter than the turnover rate of air in the chambers. Tethered calves can thus be kept relatively free to move.

\section{Literature Cited}

ARC. 1980. The Nutrient Requirements of Ruminant Livestock. Commonwealth Agric. Bureaux, Slough, U.K.

Anglaret, Y., and I. Ortigues. 1994. Determination of energy cost of standing in preruminant calves from continuous measurements in respiration chambers. Reprod. Nutr. Dev. (In press).

Baker, J. F., B. A. Buckley, G. E. Dickerson, and J. A. Nienaber. 1991. Body composition and fasting heat production from birth to 14 months of age for three biological types of beef heifers. J. Anim. Sci. 69:4406. 
Bazin, R. C., and G. J. Brisson. 1976. Plasma lipids, ketone bodies and glucose concentrations in calves fed high- and low-fat milk replacers. J. Dairy Sci. 59:1301.

Brockway, J. M., J. D. Pullar, and J. D. McDonald. 1969. Direct and indirect calorimetric techniques for the evaluation of the energy expenditure of standing and lying sheep. In: $K$. L. Blaxter, J. Kielanowski, and G. Thorbek (Ed.) Energy Metabolism of Farm Animals. pp 423-427. Oriel Press, Newcastle, U.K.

Brouwer, E. 1965. Report of sub-committee on constants and factors. In: K. L. Blaxter (Ed.) Energy Metabolism. pp 441-443. Academic Press, London.

Brown, D., T. J. Cole, M. J. Dauncey, R. W. Marrs, and P. R. Murgatroyd. 1984. Analysis of gaseous exchange in open-circuit indirect calorimetry. Med. \& Biol. Eng. \& Comput. 22:333.

Colovos, N. F., J. B. Holter, R. M. Clark, W. E. Urban, Jr., and H. H. Hayes. 1970. Energy expenditure in physical activity of cattle. In: A. Schürch and C. Wenk (Ed.) Energy Metabolism of Farm Animals. pp 89-96. Juris Druck and Verlag, Zürich, Switzerland.

Durand, D., and D. Bauchart. 1986. Variations nycthémérales de la lipémie et de la glycémie au niveau des voies afférentes et efférents du foie chez le veau préruminant. Reprod. Nutr. Dév. $26: 371$.

Durand, D., D. Bauchart, J. Lefaivre, and J.-P. Donnat. 1988. Method for continuous measurement of blood metabolite hepatic balance in conscious preruminant calves. J. Dairy Sci. $71: 1632$.

Es, van, A.J.H. 1972. Maintenance. In: W. Lenken, K. Breirem, and E. Crasemann ( $\mathrm{Ed}$.) Handbuch der Tierernährung. Zweiter Band. Leistungen und Ernährung. pp 1-54. Verlag Paul Parey, Hamburg, Germany.

Es, van, A.J.H., E. J. van Weerde, and A. M. Frens. 1966. Wärmeproduktion, Wasserverdünstung und Energiestoffwechsel bei Mastkälbern, gefüttert mit einem flüssigen Milchersatzfutter. Z. Tierphysiol. Tierernaehr. Futtermittelkd. 21:25.

Harris, P. M., P. J. Garlick, and G. E. Lobley. 1989. Interactions between energy and protein metabolism in the whole body and hind limb of sheep in response to intake. In: Y. van der Honing, and W. H. Close (Ed.) Energy Metabolism of Farm Animals. pp 167-170. Pudoc, Wageningen, The Netherlands.

Henken, A. M., H. A. Brandsma, W. van der Hel, and M.W.A. Verstegen. 1993. Circadian rhythm in heat production of limitfed growing pigs of several breeds kept at and below thermal neutrality. J. Anim. Sci. 71:1434.

Homer, J. H. 1989. Introduction to Experimental Design in Psychology. Harper and Row, New York.

Hörnicke, H. 1970. Circadian activity rhythms and the energy cost of standing in growing pigs. In: A. Schürch, and C. Wenk (Ed.)
Energy Metabolism of Farm Animals. pp 165-168. Juris Druck and Verlag, Zürich, Switzerland.

Martin, C., I. Ortigues, D. Durand, and M. Vermorel. 1991. Contribution of three tissues to energy metabolism of preruminant calves. In: C. Wenk and M. Boessinger (Ed.) Energy Metabolism of Farm Animals. pp 28-31. Institut für Nutztierwissenschaften, Zürich, Switzerland.

McLean, J. A., and G. Tobin. 1987. Animal and Human Calorimetry. Cambridge University Press, Cambridge, U.K.

McLean, J. A., and P. R. Watts. 1976. Analytical refinements in animal calorimetry. J. Appl. Physiol. 40:827.

Nienaber, J. A., Y. R. Chen, and G. L. Hahn. 1987. Energetics of activity using indirect calorimetry. In: P. W. Moe, H. F. Tyrrell, and P. J. Reynolds (Ed.) Energy Metabolism of Farm Animals. pp 164-167. Rowman \& Littlefield, Totowa, NJ.

Ortigues, I., D. Durand, and J. Lefaivre. 1994. Use of para-aminohippuric acid to measure blood flows through portal-drained viscera, liver and hindquarters. J. Agric. Sci. 122:299.

Ortigues, I., M. Petit, J. Agabriel, and M. Vermorel. 1993. Maintenance requirements in metabolizable energy of adult, nonpregnant, nonlactating Charolais cows. J. Anim. Sci. 71:1947.

Osuji, P. O. 1974. The physiology of eating and the energy expenditure of the ruminant at pasture. J. Range Manage. 27:437.

SAS. 1987. SAS/STAT ${ }^{\circledR}$ Guide for Personal Computers. SAS Inst. Inc., Cary, NC.

Susenbeth, A., and K. H. Menke. 1991. Energy requirement for physical activity in pigs. In: C. Wenk and M. Boessinger (Ed.) Energy Metabolism of Farm Animals. pp 416-419. Institut für Nutztierwissenschaften, Zürich, Switzerland.

Toullec, R., P. Thivend, and C.-M. Mathieu. 1971. Utilisation des protéines du lactosérum par le veau préruminant à l'engrais. I. Vidange stomachale comparée du lait entier et de deux laits de remplacement ne contenant que des protéines de lactosérum comme source de matières azotées. Ann. Biol. Anim. Biochim. Biophys. 11:435.

Toutain, P. L., C. Toutain, A.J.F. Webster, and J. D. McDonald. 1977. Sleep and activity, age and fatness, and the energy expenditure of confined sheep. Br. J. Nutr. 38:445.

Vermorel, M., J.-C. Bouvier, Y. Bonnet, and G. Fauconneau. 1973. Construction et fonctionnement de 2 chambres respiratoires du type "circuit ouvert" pour jeunes bovins. Ann. Biol. Anim. Biochim. Biophys. 13:659.

Vermorel, M., J. Vernet, C. Dardillat, Saido, and C. Demigné. 1989. Energy metabolism and thermoregulation in the newborn calf; variations during the first day of life and difference between breeds. Can. J. Anim. Sci. 69:103.

Wenk, C., and A.J.H. van Es. 1976. Energy metabolism of growing chickens as related to their physical activity. In: M. Vermorel (Ed.) Energy Metabolism of Farm Animals. pp 189-192. G. de Bussac, Clermont Ferrand, France. 